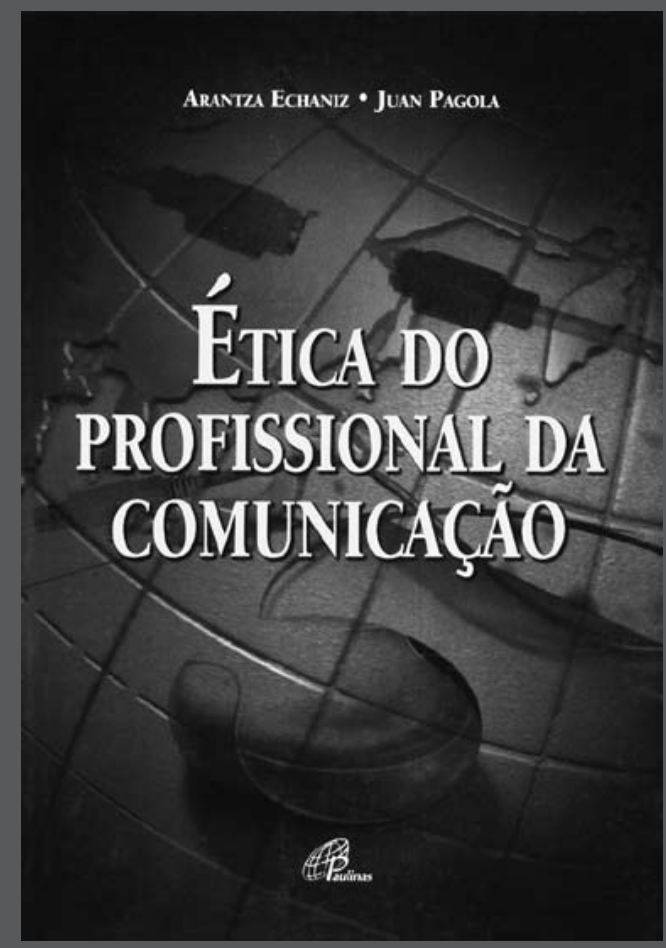

\title{
Ética do profissional da comunicação
}

Arantza Echaniz e Juan Pagola

São Paulo:

Paulinas, 2007.

372 páginas

(Tradução de Cristina Paixão Lopes)

Wilma Pereira Tinoco Vilaça

- Doutoranda pelo Programa Ciências da Comunicação da Escola de Comunicações e Artes da Universidade de São Paulo (ECA-USP)

- Coordenadora do Curso de Pós-Graduação Lato Sensu em

Comunicação Empresarial do Centro Universitário de Belo Horizonte (UNI-BH)

- Professora do Curso de Relações Públicas do UNI-BH

-wilma.vilaca@gmail.com

-wilma.vilaca@usp.br 


\section{Ética do profissional da comunicação}

ão maduros os tempos para se falar em ética profissional. São maduros os temDos para fazer com que os jovens, principalmente aqueles que estão em vias de alcançar o exercício profissional, possam ser confrontados com os limites técnicos, humanos, jurídicos e éticos que irão pautar tal atuação. São maduros os tempos para que as pessoas reconheçam que, sem a garantia de direitos, não há ética possível. Para Aristóteles, o exercício último da ética se dá no âmbito da política, porque o homem é um ser de ação e toda ação decorre de uma escolha. Ser ético é conseguir fazer escolhas de uma conduta considerada boa em detrimento de outra.

E, se falar de ética evoca sempre essa noção de respeito em relação ao outro, a necessidade de estar atento para o reconhecimento da diferença e conseguir mobilizar forças para, em um mundo tão permissivo e conturbado, tão frágil de valores, ter coragem pessoal para não racionalizar a má conduta ética e dizer não às suas armadilhas cotidianas, creio, então, que, hoje, são as universidades que têm a oportunidade de abrir espaço para realizar o bom combate: por que é tão difícil ser ético na sociedade contemporânea?

Nesse sentido, o livro de Arantza Echaniz e Juan Pagola, Ética do profissional de comunicação, satisfaz a três importantes requisitos: 1 . consegue falar de um tema delicado e controverso - por tudo que se descortina na vida cotidiana - de uma forma fluida, sem perder sua densidade. Isso talvez seja uma resultante de sua própria autoria: ela, doutora em Ciências Econômicas e Empresariais; ele, formado em Ciências da Informação. Ela, com especialização em ética empresarial e ele, docente da disciplina Valores Sociais e Direito da Comunicação, ambos atuando na Faculdade de Deusto, em Bilbao, Espanha. A sensação que nos toma de assalto à primeira leitura é que os autores fundiram competências e formações individuais para que o livro tivesse um formato diferenciado e pudesse atender objetivos distintos; 2 . a leitura se transmuta em rica oportunidade para a reflexão e nos obriga a observar o duplo movimento de tese e antítese; a perceber nos recortes de cada capítulo o interessante jogo de conteúdos; 3. e, ademais, para os professores de disciplinas de ética em cursos de comunicação, o livro tem um importante valor agregado: ao final de cada capítulo, traz modelos de exercícios que podem ser aplicados com base no conteúdo proposto, bem como elenca a bibliografia que pode ser consultada a respeito do que fora tratado até então. Assim, ele é capaz de estimular a busca por mais fundamentos ao mesmo tempo em que é, em si mesmo, grande referência.

Escrito com vigor e em uma linguagem bem acessível, Ética do profissional de comunicação se divide em duas partes e, em cada uma delas, somos brindados com uma introdução que tem como objetivo situar o leitor na temática que será então descortinada.

Na primeira introdução, os autores se preocupam em destacar que o protagonismo midiático tem como importante consequência a sua constante vigília, que alimenta o 
debate sobre as fronteiras de sua atuação. Preocupados em resguardar determinados princípios, os autores alertam sobre os efeitos funestos advindos de uma possível "colisão entre as idéias de liberdade de expressão e de respeito à dignidade do homem" (ECHANIZ e PAGOLA, 2007, p. 13). Para tanto, desenvolvem quatro capítulos que têm como fios condutores o fenômeno da globalização e a sociedade pós-moderna. É no embate entre as questões de liberdade de expressão e o direito à informação, entre a influência do poder político/econômico e os sistemas mais usuais de manipulação midiática, que os autores se esmeram. Apresentam pertinente revisão de bibliografia, dados e experiências reais, de domínio público e, em seguida, apresentam exercícios que podem ser utilizados tanto como exercício crítico-reflexivo quanto para aplicação didático-pedagógica conduzida em salas de aulas por professores que ministrem a disciplina de ética profissional.

Na segunda introdução, no entanto, os temas se vinculam muito mais aos aspectos concretos de funcionamento dos meios e da conduta do profissional, elucidando os dilemas inerentes ao labor diário. São cinco capítulos e o de número cinco, por exemplo, ao tratar dos direitos e deveres do profissional da comunicação, dedica grande parte de seu conteúdo para falar da questão do sigilo profissional, destacando que "não constitui um privilégio ou uma situação de impunidade, mas amplia o âmbito de responsabilidade" (ECHANIZ e PAGOLA, 2007, p. 176). Nesse sentido, parece natural que sejam, em seqüência, apresentados os capítulos que tratam dos direitos e deveres do receptor, os mecanismos de auto-regulação dos meios, a questão da ética da comunicação em relação às novas tecnologias e a comunicação na dinâmica Norte-Sul. Ou seja, a leitura pode ser arquitetada de acordo com os interesses mais imediatos do leitor ou vir num crescendo, numa sequência lógica que lhe permita avançar de forma a construir um corpo de conhecimentos bastante consistente sobre a temática.

Um único senão deve ser feito. Concretamente, o livro é direcionado tão-somente à área de Jornalismo. No Brasil, onde o campo mater da Comunicação congrega as subáreas de Jornalismo, Relações Públicas e Publicidade/Propaganda, será difícil indicá-lo como leitura para os que não sejam, por suas especificidades, oriundos do Jornalismo. Em contrapartida, tendo como público-alvo os jornalistas, o livro atenta para a necessidade de que esse profissional rediscuta a ética e possa refletir sobre a ação humana, pois isso, pela natureza de sua atuação, o aproximaria ainda mais da realidade.

Então, para finalizar, nada mais justo que resgatarmos Aristóteles, em Ética a Nicômano, para reafirmar que se os homens se tornam bons pela educação - por ele entendida como a formação da personalidade do indivíduo por meio de uma boa família, em uma boa cidade (a pólis) -, que esse livro contribua para forjar bons homens, cidadãos conscientes de suas responsabilidades e das ações que praticam em qualquer espaço de sua vida profissional e pessoal. Assim o espero. 